\title{
Empirical Research of the Enterprise Classroom Management in Private Colleges
}

\author{
Huining Guo \\ General Education Center, Xining College, Xi'an 710123, China \\ email:1073475633@qq.com
} Keywords: Private colleges; Enterprise class management; Fuzzy analytic hierarchy process
(FAHP); Evaluation index system

\begin{abstract}
This paper investigates the applications of enterprise management mode to classroom management of private colleges. A complete enterprise class management mode is formed through the role and institutional changes. Finally, the effect of the enterprise class management mode is objectively and scientifically evaluated by fuzzy analytic hierarchy process (FAHP). The results show that the effect of the enterprise class management is satisfactory, and it is worth to be improved and promoted. This study has certain reference to teaching reform and developing the modern vocational education of private colleges.
\end{abstract}

\section{Introduction}

Chinese private higher education institutions emerged in the 1980s, and it has decades of development history. At the beginning of the its development, the management method mostly emulates public universities and there is nothing unique about it. As Chinese higher education reform continues to deepen, an own school management method is urgently needed in private colleges. In recent years, the enterprise management has been introduced into Chinese private colleges and the private colleges are finding their own ways to development. At the same time, the document called "On speed up the development of modern vocational education" makes the applied technology talents training target gradually clear in private colleges. Under this great opportunity of transitional development, private colleges need to reform the existing traditional teaching methods to adapt to the cultivation of applied personnel and the demand of social development.

In recent years, there have been few studies to introduce enterprise management mode into the management of private colleges. They mainly focus the implementation feasibility in private colleges administration from the theoretical level ${ }^{[1-2]}$. Therefore, it is necessary to further carry out empirical study on enterprise management combining with the class teaching management in private colleges. This is beneficial to creating a new situation of the private college development and to enhancing the influence of enterprise management mode on teaching reform. Through this study, we hope to reduce or eliminate these problems and rationalize the relationship between teachers and students, which allows students to participate in classroom management and improves the students' ability of self control. Therefore, through the enterprise management in classroom, students gradually have the thinking and behavior of enterprise employees, which lay the foundation for students quickly adapting to the real business management after graduation ${ }^{[4]}$.

\section{The transformation of traditional classroom management to enterprise management}

\section{Turn the classroom into an "enterprise workshop"}

Enterprise management needs to transform the traditional teaching of theory in classroom to teaching knowledge, learning technology and improving the professional ethics in the enterprise workshop. Only by expanding the function of the classroom from consciousness, we can better implement the new management model.

\section{Change the role of the Manager and the Managed}

The traditional classroom management in private colleges is based on a clear and unified school management system. The counselors always manage students by listening to lectures, checking 
attendance, and other rewards and punishments; while teachers are only responsible for teaching theory. This leads to students thumbing their nose at their teachers, and some students can direct into confrontation with teachers in the classroom. So, the teachers have low status and lack teaching enthusiasm. Enterprise classroom management takes the teachers and students as the main body of the classroom management, and gradually dilutes the counselors to the classroom management. In this way, teachers have a dual role, not only teaching and educating people, but also the workshop managers, and make bold use of enterprise management system for management; at the same time, the role of the students has changed, with the learners, management of small assistants and business employees. Management assistant is to set up the flow management of small assistant position, and helps teachers in class management.

\section{Change the traditional management system to the enterprise management system}

The main content of the traditional classroom management system is based on the students' classroom discipline and other performance, containing in verbal praise or criticism, the usual scores and so on. For students, many management systems are useless. Enterprise management is in accordance with the requirements of the enterprise standard, changing the traditional normal score plus the final exam results as the final result of this course; all students are required to complete 4 times related practical works per semester, which is considered as the basic content of the process assessment.

\section{The evaluation index system of enterprise classroom management}

After enterprise classroom management mode enters into the classroom, its effect need to corresponding evaluation. This study is based on the actual classroom management to determine the evaluation index system of enterprise classroom management from the management objective, management content, the implementation of enterprise management, the role of teachers and students by fitness. As shown in Table 1.

Table 1 Evaluation index system of enterprise classroom management

\begin{tabular}{|c|c|c|}
\hline \multirow{21}{*}{$\begin{array}{l}\text { Evaluation } \\
\text { index system } \\
\text { of enterprise } \\
\text { classroom } \\
\text { management }\end{array}$} & \multirow{5}{*}{$\begin{array}{l}\text { B1 The } \\
\text { management } \\
\text { objective }\end{array}$} & C1 Strengthen the cultivation of applied talents \\
\hline & & C2 Weakening theory teaching, strengthen practical teaching \\
\hline & & C3 Strengthen the cultivation of professional ethics \\
\hline & & C4 Strengthen the cultivation of professional technical quality \\
\hline & & C5 Strengthen the cultivation of enterprise culture \\
\hline & \multirow{5}{*}{$\begin{array}{l}\text { B2 The } \\
\text { management } \\
\text { content }\end{array}$} & C6 Management of late, leave early and absenteeism \\
\hline & & C7 Management of students playing mobile phone \\
\hline & & C8 Management of sleeping and chatting in class \\
\hline & & C9 Management of content design of practical work \\
\hline & & C10 Management of rewards and punishments \\
\hline & \multirow{4}{*}{$\begin{array}{c}\text { B3 The } \\
\text { implementation } \\
\text { of enterprise } \\
\text { management }\end{array}$} & C11 Implementation of enterprise attendance \\
\hline & & C12 Implementation of enterprise assessment \\
\hline & & C13 The implementation of enterprise of the rewards and punishments \\
\hline & & $\begin{array}{c}\begin{array}{c}\text { C14 The Satisfaction degree of implementation of enterprise classroom } \\
\text { management }\end{array} \\
\text { mang }\end{array}$ \\
\hline & \multirow{3}{*}{$\begin{array}{l}\text { B4 The role } \\
\text { fitness of } \\
\text { teachers }\end{array}$} & C15 Fitness for the role of teaching and educating people \\
\hline & & C16 Fitness for the role of workshop manager \\
\hline & & $\begin{array}{c}\text { C17 Teachers' satisfaction degree of implementation of enterprise } \\
\text { classroom management }\end{array}$ \\
\hline & \multirow{4}{*}{$\begin{array}{l}\text { B5 The role } \\
\text { fitness of } \\
\text { students }\end{array}$} & C18 Fitness for the role of learners \\
\hline & & C19 Fitness for the role of small assistant management \\
\hline & & C20 Fitness for the role of enterprise employees \\
\hline & & $\begin{array}{c}\text { C21 Students' satisfaction degree of implementation of enterprise } \\
\text { classroom management. }\end{array}$ \\
\hline
\end{tabular}




\section{Evaluation of the Enterprise Classroom Management Based on Fuzzy Analytic Hierarchy Process}

The evaluation of the effect of enterprise classroom management in private colleges is a evaluation work which involves many factors and has a fuzzy nature. In order to evaluate objectively and fairly, the fuzzy analytic hierarchy process is used to determine the weights of the indexes, then the fuzzy evaluation matrix is given according to the fuzzy set theory. The comprehensive evaluation is conducted from the bottom up, and then the effect of the enterprise classroom management of private colleges is evaluated scientifically and effectively. Specific evaluation process is as follows:

\section{Determining the evaluation set}

The fuzzy AHP model is divided into three layers, the top layer is the target layer; middle layer is the standard layer; the lowest layer is the indicator layer, as shown in Table 1.

\section{Determining the weight of the evaluation index}

The evaluation results are divided into four grades when the effect of the enterprise classroom management of private colleges is evaluated. Evaluation set $\mathrm{V}=\{$ very satisfied, comparatively satisfied, basic satisfied, dissatisfied $\}$, The corresponding score was $G=\{90$ points and above, 80 points and above, 60 points and above, 60 points or fewer $\}$. The determination of the weight of the evaluation index will directly affect the final evaluation results, so we must determine the weight of each index scientifically and reasonably. In this paper, the fuzzy analytic hierarchy process is used to determine the weight of each index. The results are shown in Table 2.

Table 2 Index weight value

\begin{tabular}{cccc}
\hline $\begin{array}{c}\text { First stage index index } \\
\text { indicator }\end{array}$ & Weight & Two stage index & Weight \\
\hline \multirow{3}{*}{ B1 } & & C1 & 0.27 \\
& & C2 & 0.23 \\
& & C3 & 0.22 \\
& & C4 & 0.18 \\
B2 & C5 & 0.10 \\
& & C6 & 0.25 \\
& & C7 & 0.24 \\
& & C8 & 0.16 \\
B3 & C9 & 0.22 \\
& & C10 & 0.13 \\
& \multirow{3}{*}{0.24} & C11 & 0.34 \\
B4 & C12 & 0.22 \\
& & C13 & 0.28 \\
& \multirow{3}{*}{0.12} & C14 & 0.16 \\
B5 & & C16 & 0.47 \\
& & C17 & 0.35 \\
& \multirow{2}{*}{0.08} & C18 & 0.18 \\
& & C20 & 0.31 \\
& & C21 & 0.29 \\
\end{tabular}

\section{Establishing the Membership Matrix}

This study selected the "Ideological and moral cultivation and legal basis" course in a private university's for two semester pilot in Shaanxi. There were a total of 20 classes and about 3000 students to participate in the pilot. We used the questionnaire survey method to each of the indicators according to the predetermined set of evaluation and comprehensive evaluation, the membership degree of each index corresponding to the evaluation set is obtained, as shown in Table 3. 
Table 3 Index membership value

\begin{tabular}{cccccc}
\hline \multirow{2}{*}{$\begin{array}{c}\text { First } \\
\text { stage }\end{array}$} & Two & \multicolumn{4}{c}{ Membership degree } \\
stage & index & very & comparativel & basic \\
& satisfie & y satisfied & satisfacti & dissatisfied \\
\hline & C1 & 0.5 & 0.2 & 0.3 & 0 \\
& C2 & 0.6 & 0.2 & 0.1 & 0.1 \\
B1 & C3 & 0.4 & 0.4 & 0.1 & 0.1 \\
& C4 & 0.6 & 0.2 & 0.2 & 0 \\
& C5 & 0.7 & 0.1 & 0.2 & 0 \\
& C6 & 0.6 & 0.2 & 0.1 & 0.1 \\
& C7 & 0.6 & 0.3 & 0.1 & 0 \\
B2 & C8 & 0.5 & 0.3 & 0.2 & 0 \\
& C9 & 0.6 & 0.1 & 0.2 & 0.1 \\
& C10 & 0.2 & 0.7 & 0.1 & 0 \\
& C11 & 0.2 & 0.4 & 0.3 & 0.1 \\
B3 & C12 & 0.3 & 0.4 & 0.2 & 0.1 \\
& C13 & 0.7 & 0.1 & 0.2 & 0 \\
& C14 & 0.3 & 0.4 & 0.3 & 0 \\
& C15 & 0.6 & 0.2 & 0.1 & 0.1 \\
B4 & C16 & 0.4 & 0.4 & 0.1 & 0.1 \\
& C17 & 0.2 & 0.6 & 0.2 & 0 \\
& C18 & 0.5 & 0.4 & 0.1 & 0 \\
& C19 & 0.3 & 0.4 & 0.3 & 0 \\
B5 & C20 & 0.5 & 0.1 & 0.3 & 0.1 \\
& C21 & 0.4 & 0.2 & 0.3 & 0.1 \\
\hline
\end{tabular}

\section{Comprehensive Evaluation}

\section{Single level fuzzy comprehensive evaluation}

From Table 2, the weight vector $Y_{1}$ of the first criteria is obtained:

$Y_{1}=(0.27,0.23,0.22,0.18,0.10)$

From Table 3, the membership matrix of the fuzzy evaluation of the first criteria is obtained:

$$
R_{1}=\left[\begin{array}{cccc}
0.5 & 0.2 & 0.3 & 0 \\
0.6 & 0.2 & 0.1 & 0.1 \\
0.4 & 0.4 & 0.1 & 0.1 \\
0.6 & 0.2 & 0.2 & 0 \\
0.7 & 0.2 & 0.1 & 0
\end{array}\right]
$$

According to fuzzy comprehensive evaluation model $S=Y \circ R$, the evaluation vector of the first criteria can be calculated:

$$
S_{1}=Y_{1} \circ R_{1}=(0.54,0.24,0.17,0.05)
$$

The same method can be used to calculate the evaluation vector of other criteria.

According to the principle of maximum membership degree and $\operatorname{MAX}(0.48,0.29,0.18$, $0.05)=0.48$, the evaluation of the effect of the enterprise classroom management in private colleges is "comparatively satisfactory". To score, the comprehensive score of the effect of enterprise classroom management can be calculated:

$G=S^{*} \circ C^{T}=0.48 \times 100+0.29 \times 85+0.18 \times 60+0.05 \times 40=85.45$

\section{Conclusions and Recommendations}

This study tested enterprise classroom management mode through the ideological and political 
theory course in private colleges, and the fuzzy analytic hierarchy process is used to evaluate the effect of the management. The results show that the management mode is comparatively satisfied, and it is more suitable for the transformation and development of private colleges with the enterprise classroom management mode. Its outstanding performance is: first, it greatly improves the teachers' teaching status, and teachers' power of the discourse increases in classroom management. The emotional distance between teachers and students is shortened, and the barriers to classroom teaching are reduced. Second, students' self control ability is improved. Most students can consciously stay away from the phone, sleeping and chat. The truant students are significantly decreased. Third, the students' awareness of the staff is enhanced through the completion of the work of practice. After a year of pilot, the students' practical ability is improved and the students have "prospective employee" attitude. In short, the enterprise classroom management "held" Classroom discipline, teachers' teaching is changed 'flexible "and students' staff awareness is enhanced $^{[5-7]}$.

In order to make the enterprise classroom management mode can be further improved and promoted, some suggestions are put forward: First, the executive power of enterprise class management should be improved. Because the scope of the pilot, after all, is limited, a lot of teachers and students are not enough to understand the enterprise classroom management mode. So, we advice that all the ideological and political theory courses are implemented, and this mode should be introduced to other courses gradually. Second, we propose the private colleges support the management mode at policy, material, financial and other aspects. Our ultimate goal is to train students to be qualified. Through the pilot we find that most of students are positive. According to this trend, we believe that we should increase the scope and intensity of the reward students, but the material reward is limited, we hope the school can strongly support.

\section{References}

[1] Li Dan-yan. Discussion on the feasibility of the enterprise management of private colleges [J]. Labor security world.2013 (05):126-127.

[2] Huang Wei, Yang Jie. Analysis on the quasi-entrepreneurial management of class in private university [J]. Private education research. 2015(03):26-27.

[3] FU Wen-mao. Discussion on the classroom management of ideological and political course teaching in private universities [J]. Modern Business Trade Industry. 2013(15):144.

[4] Guo Hui-ning, Bian Guo-dong. Evaluation of the effects of the practice teaching in private colleges [J]. Education review. 2015(04):125-129.

[5] Xiao Yan-ling, Wang Hui-li, Li Hua-xi. Evaluation and classification management about the petrochemical enterprise's supplier based on AHP method [J]. Journal of Daqing Petroleum Institute.2007.(6): 108 - 111.

[6] Yin Wen-tao, Li Zheng, Zhai Zhen-dong. Thinking on the social forces developing the higher vocational education [J]. Education and occupation. 2014(26):8-10.

[7] Peng L, Xiaoping Z. Social Stratification and Cooperative Behavior in Spatial Prisoners' Dilemma Games [J]. PLOS ONE, 2015, 10(7): e0131005. 